\title{
Effects of irrigation systems on yield and physical characteristics of date (Phoenix dactylifera .L) cv. 'Medjool'
}

\author{
Fouzia Alla ${ }^{1 *}$, Kawtar Jdaini ${ }^{1}$, Jamal Mimouni ${ }^{2}$, and Mohammed Aziz Elhoumaizi ${ }^{1}$ \\ ${ }^{1}$ Laboratory of Agricultural Production Improvement, Biotechnology and Environment (LAPABE), \\ Faculty of Sciences, University Mohammed First, 717 Oujda 60000, Morocco. \\ ${ }^{2}$ National Agency for the Development of Oasis and Argan Areas (ANDZOA), Bouarfa, Morocco.
}

\begin{abstract}
The shortage of irrigation water pooled with the effect of climate change and inadequate management in oases; affects the sustainability of the oasis ecosystem. Irrigation, as practiced in these oases, is not conducted according to the real water requirements of the crops, this management can induce water stress which affects the physical characteristics of the dates cultivated and consequently yield production, or on the contrary a significant water intake and a waste of the resource. This study investigated two irrigation systems; drip-irrigation, which is currently applied under date palms in the Moroccan oases, and the newly introduced underground irrigation (Micro-porous irrigation) .The aim of this work, was to assess the effects of different types of irrigation system on yield and physical quality parameters of 'Medjool' dates. Fruit quality assessment including fruit weight, length, breadth, pulp thickness, stone weight, length, breadth, number and average weight of bunches fruit per tree were evaluated, to identify the most effective irrigation system for date palm.
\end{abstract}

\section{Introduction}

Date palm (Phoenix dactylifera L.), one of the oldest known fruit crops, belonging to Arecaceae family. It is an important horticultural crop and it represents the heart of oasis cultivation systems [1]. Its cultivation around the world, mainly for its edible sweet fruits, has a considerable economic significance, which improves agricultural yields in arid environments [2]. The chemical composition of dates including the minerals, proteins, fats, carbohydrates, vitamins, and dietary fibers, are the main nutritional values that affect the quality of dates. Its richness plays a major role in humans health, showing a high antioxidant, anticancer, hepatoprotective, neuroprotective, nephroprotective, gastrointestinal protective, antidiabetic, antihyperlipidemic potentials [3].

*Corresponding author: fouzia.alla@gmail.com 
Located in an arid and hostile environment, the oasis constitutes a unique ecosystem, based on the right balance of three elements: water, soil quality, and the presence of date palms whose parasol-shaped foliage creates a real microclimate. This tree is considered as one of the oldest fruit species, its cultivation was practiced by ancient civilizations for centuries, showing a great ecological and socio-economic importance due to its high plasticity, and adaptation to extreme pedo-climactic conditions [4] The management of water resources is the major factor influencing the economic and social development of the Saharan oases. In Morocco, the date palm is the key species in oasis systems; it occupies a privileged place in oasis arboriculture and provides jobs for most of the local population. Moroccan date palm counts so far around 6.6 million palm trees spread on 51,000 hectares concentrated mainly in four regions, Tafilalet-Daraa, Souss-massa, Guelmil-Oued Noun and Figuig [5], composed of 453 cvs. including high proportion of Khalts (originating from natural palm seedlings) and other high value cultivars such as Boufeggous, Medjool, Bouskri, and Aziza bouzid [6], with an significant average harvest of 129,562 tons in 2017[7]. However, these sub-desert areas are in a critical situation due to the scarcity of their water resources. The water shortage of irrigation water pooled with the effect of climate change and inadequate management in oases; pose a significant threat to the sustainability of the oasis ecosystem. The availability of water in quantity and quality associated with irrational use of irrigation water in the face of hostile agro-climatic conditions are the main factors causing negative repercussions in the oasis ecosystem. As a result of the poor management of water on the scale of farms and their environment, many consequences and negative effects on the economy of palm growers can be observed in these zones.

Therefore, finding ways to increase the quality of dates and production through irrigation systems is of great importance. In morocco, the most used method of irrigation is drip irrigation, this system has helped sustain the production of date palms and other crops, however, its use in the sub-desert areas has various problems, mainly for its inability to keep water safe from high evaporation rates, the spread of weeds around date palms, cracks in the channels leading to water leaks, and damage of canals by animals. As an alternative to this system, it would be favorable to use underground irrigation. This technique is defined as a slow release, sub-surface irrigation system. It is based on a unique microtechnology from $0-300 \mu \mathrm{m}$, which significantly reduces water use with limited maintenance, at a reduced cost. This promising water saving technology enables increased irrigation efficiency by up to $70 \%$, minimizing losses of evaporation, runoff and deep percolation.

Given the issue of shortage of water, it is important to examine the comparative performance of various irrigation systems predominantly in desert regions. This research will focus on analyzing the effects of underground irrigation systems on yield and physical characteristics of dates, as well as a comparative analysis of drip irrigation systems used in the Moroccan oasis.

\section{Materials and methods}

\subsection{Experimental site location}

This study was conducted out on a plantation of 50ha in Figuig (East of morocco), (N $\left.32^{\circ} 09^{\prime} 05^{\prime \prime} \mathrm{W} 1^{\circ} 17^{\prime} 47^{\prime \prime}\right)$, for two successive years (2019-2020). The climate of the study area is arid with an annual mean temperature of $32^{\circ} \mathrm{C}$ and annual mean precipitation of 92.4mm (2009-2019). 


\subsection{Plant material}

The variety used is 'Medjool'. This variety of date palm is essentially characterized by its worldwide reputation expressed by the large size of its fruit and its excellent date palm quality generating better commercial added value. The date palms were planted in 2011 at a density of $6 \mathrm{~m} \times 6 \mathrm{~m}$, the area reserved for this test is $600 \mathrm{~m}^{2}$.

The experiment was conducted in two blocks, comprising two different irrigation systems:

i) An underground irrigation system was installed with a circle of $6 \mathrm{~m}$ for each date tree, with a flow rate of $8 \mathrm{l} / \mathrm{m} * \mathrm{~h}$.;

ii) A drip irrigation system was installed with two lateral lines for each row of date palm, with 6 drippers and a flow rate of 96 1/h. Each block consists of 208 trees and 48 trees per replicate was used (B1, B2, B3, and B4).

The annual irrigation water amount supplied to date palm (Phoenix dactylifera L.) following the farmer regime were $46,08\left(\mathrm{~m}^{3} /\right.$ tree) under drip irrigation system including $7,68\left(\mathrm{~m}^{3} /\right.$ tree $)$ of water losses , and $20,736\left(\mathrm{~m}^{3} /\right.$ tree $)$ for the underground irrigation system (micro-irrigation) including 1,536 $\left(\mathrm{m}^{3} /\right.$ tree) of water losses. Fruits samples were harvested from each tree and fruit bunches at the 'Tamr' fruit maturity stage, employed simple random sampling technique. Dates were imported to the laboratory for analysis.

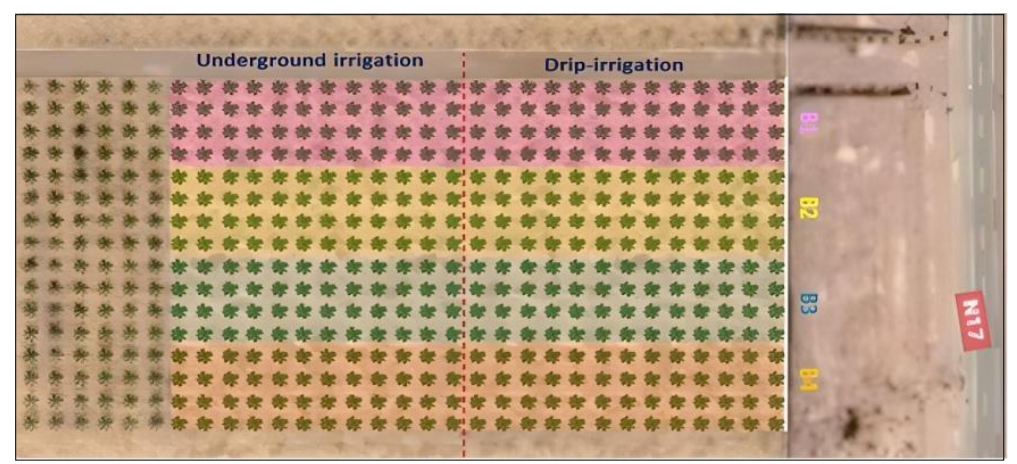

Fig. 1. Experimental plan

\subsection{Physical characteristics}

- Weight and stone weight were measured by using an electric balance with $0.01 \mathrm{gm}$ sensitivity and average weight per fruit was calculated (RADWAG PS 360.R2).

- Pulp stone ratio was calculated by dividing the weight of pulp by stone weight.

- Fruit length, breadth, thickness was measured by using a digital Vernier caliper with $0.01 \mathrm{~mm}$ accuracy.

\subsection{Bunches fruit characterization}

The evaluation of effect of two methods of irrigation, drip irrigation and underground irrigation, on bunches fruit characterization, is based in determination of the unit yield (in $\mathrm{kg}$ / tree): the total number and average weight of bunches fruit per tree. 


\subsection{Statistical analysis}

The experimental data were analysed by using two-way analysis of variance (ANOVA) using SPSS statistics 20 edition. The effects of irrigation system and their interactions with different parameters were estimated and assessed using ANOVA, in particular least significant differences (LSD) along with using a significance level at $(\mathrm{P} \leq 0.05)$ using $\mathrm{F}$ test.

\section{Results}

\subsection{Physical characteristics}

The analysis of the physical characteristics of date palms is presented below (Table 1).

Irrespective of the type of irrigation system, the fruit weight, breadth, length, and Pulp thickness did not significantly affected $(\mathrm{p} \leq 0.05)$. Underground irrigation resulted in the highest fruit weight, breadth, length, and pulp thickness $\left(18.40 \pm 2.68 \mathrm{~g}\right.$ fruit $^{-1}, 24.18 \pm 1.69$ $\mathrm{mm}$ fruit $^{-1}, 41.36 \pm 2.6 \mathrm{~mm}^{\text {fruit }}{ }^{-1}$ and $\left.6.25 \pm 0.25 \mathrm{~mm}_{\text {fruit }}{ }^{-1}\right)$ compared to drip irrigation system $\left(15.56 \pm 2.8 \mathrm{~g}_{\text {fruit }}{ }^{-1}, 23 \pm 1.83 \mathrm{~mm}_{\text {fruit }}{ }^{-1}, 38.25 \pm 2.43 \mathrm{~mm}_{\text {fruit }}{ }^{-1}\right.$, and $5,82 \pm 0,42 \mathrm{~mm}$ fruit- $\left.{ }^{1}\right)$, respectively. The irrigation systems significantly affect only stone weight while stone breadth and length, were not significantly affected with irrigation systems. Underground irrigation resulted in highest stone weight, breadth and length $(1.30 \pm 0.08 \mathrm{~g}$ fruit $^{-1}, 9.09 \pm 0.48 \mathrm{~mm}_{\text {fruit }}{ }^{-1}$, and24.18 $\pm 1.88 \mathrm{~mm}$ fruit $^{-1}$ ) compared to drip irrigation system $\left(1.14 \pm 0.14 \mathrm{~g} \mathrm{fruit}^{-1}, 9.09 \pm 0.42 \mathrm{~mm}\right.$ fruit $^{-1}$, and $23.45 \pm 1.44 \mathrm{~mm}$ fruit ${ }^{-1}$ ) respectively (Table 2).However, there were great savings of irrigation water using underground irrigation systems compared to drip irrigation system. This is consistent with, [8-9]; and [10]; who reported that irrigation systems have no effect of on date fruit quality. Contrarily, research findings reported from the Middle East and North African countries claimed that irrigation systems influence date palm fruit quality $[11,12,13,14,15,16,17]$. Furthermore, several studies found the effect of different farming practices on physical characteristics of dates, such as fertilization treatments [18], pollination and pruning on fruit quality [19-20]. In our case, the two blocks of experiment were treated with the same fertilization treatments, the same farming practices and pollinated with the same mixture of pollen, however the mixture was different from 2019 to 2020 . 
Table 1.Effect of irrigation systems on physical characteristics of 'Medjool' dates per year

\begin{tabular}{|c|c|c|c|c|c|c|c|c|c|c|c|}
\hline \multirow{2}{*}{\multicolumn{2}{|c|}{$\begin{array}{l}\text { Irrigation } \\
\text { system }\end{array}$}} & \multicolumn{3}{|c|}{ Fruits } & \multicolumn{2}{|c|}{ Pulps } & \multicolumn{3}{|c|}{ Seeds } & \multirow{3}{*}{$\begin{array}{l}\text { Ratio S/D } \\
7,11 \pm 0,72\end{array}$} & \multirow{3}{*}{$\begin{array}{c}\begin{array}{c}\text { Ratio } \\
\text { P/D }\end{array} \\
92,89 \pm 0,72\end{array}$} \\
\hline & & $\begin{array}{l}\text { Weight } \\
\text { (g) }\end{array}$ & $\begin{array}{c}\text { Breadth } \\
(\mathrm{mm})\end{array}$ & $\begin{array}{c}\begin{array}{c}\text { Length } \\
(\mathrm{mm})\end{array} \\
\end{array}$ & $\begin{array}{c}\text { Thickness } \\
(\mathrm{mm})\end{array}$ & $\begin{array}{c}\text { Weight } \\
\text { (g) }\end{array}$ & $\begin{array}{c}\text { Weight } \\
\text { (g) }\end{array}$ & $\begin{array}{c}\text { Breadth } \\
(\mathrm{mm})\end{array}$ & $\begin{array}{c}\begin{array}{c}\text { Length } \\
(\mathrm{mm})\end{array} \\
\end{array}$ & & \\
\hline \multirow{2}{*}{. } & ๙ิ & $18,19 \pm 1,65$ & $24,83 \pm 0,30$ & $40,68 \pm 0,64$ & $6,16 \pm 0,23$ & $16,91 \pm 1,65$ & $1,28 \pm 0,01$ & $9,50 \pm 0,24$ & $24,89 \pm 0,35$ & & \\
\hline & $\frac{a}{i}$ & $12,92 \pm 0,34$ & $21,16 \pm 0,47$ & $35,81 \pm 0,93$ & $5,48 \pm 0,27$ & $11,92 \pm 0,33$ & $1,00 \pm 0,01$ & $8,68 \pm 0,02$ & $22,01 \pm 0,29$ & $7,76 \pm 0,19$ & $92,24 \pm 0,19$ \\
\hline \multirow{2}{*}{ 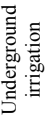 } & ๙ิ઼ & $19,98 \pm 1,28$ & $25,87 \pm 0,50$ & $43,78 \pm 1,37$ & $6,36 \pm 0,22$ & $18,61 \pm 1,22$ & $1,38 \pm 0,10$ & $9,57 \pm 0,09$ & $26,06 \pm 0,72$ & $6,90 \pm 0,47$ & $93,10 \pm 0,47$ \\
\hline & $\stackrel{2}{\circ}$ & $16,83 \pm 2,87$ & $22,48 \pm 0,38$ & $38,94 \pm 1,46$ & $6,13 \pm 0,22$ & $15,61 \pm 2,86$ & $1,22 \pm 0,03$ & $8,61 \pm 0,13$ & $22,29 \pm 0,57$ & $7,47 \pm 1,02$ & $92,53 \pm 1,02$ \\
\hline
\end{tabular}

Table 2.Effect of irrigation systems on physical characteristics of 'Medjool ' dates

\begin{tabular}{|c|c|c|c|c|c|c|c|c|c|c|}
\hline \multirow{2}{*}{$\begin{array}{l}\text { Irrigation } \\
\text { system }\end{array}$} & \multicolumn{3}{|c|}{ Fruits } & \multicolumn{2}{|c|}{ Pulps } & \multicolumn{3}{|c|}{ Seeds } & \multirow[b]{2}{*}{ Ratio S/D } & \multirow[b]{2}{*}{ Ratio P/D } \\
\hline & $\begin{array}{c}\text { Weight } \\
\text { (g) }\end{array}$ & $\begin{array}{c}\text { Breadth } \\
(\mathrm{mm})\end{array}$ & $\begin{array}{c}\text { Length } \\
(\mathrm{mm})\end{array}$ & $\begin{array}{c}\begin{array}{c}\text { Thickness } \\
(\mathrm{mm})\end{array} \\
\end{array}$ & $\begin{array}{c}\text { Weight } \\
\text { (g) }\end{array}$ & $\begin{array}{c}\text { Weight } \\
\text { (g) }\end{array}$ & $\begin{array}{c}\text { Breadth } \\
(\mathrm{mm})\end{array}$ & $\begin{array}{c}\text { Length } \\
(\mathrm{mm})\end{array}$ & & \\
\hline Drip irrigation & $15,56 \pm 2,80$ & $23,00 \pm 1,83$ & $38,25 \pm 2,43$ & $5,82 \pm 0,42$ & $14,42 \pm 2,70$ & $1,14 \pm 0,14$ & $9,09 \pm 0,42$ & $23,45 \pm 1,44$ & $7,43 \pm 0,60$ & $92,57 \pm 0,60$ \\
\hline $\begin{array}{l}\text { Underground } \\
\text { irrigation }\end{array}$ & $18,40 \pm 2,68$ & $24,18 \pm 1,69$ & $41,36 \pm 2,6$ & $6,25 \pm 0,25$ & $17,11 \pm 2,62$ & $1,30 \pm 0,08$ & $9,09 \pm 0,48$ & $24,18 \pm 1,88$ & $7,19 \pm 0,81$ & $92,81 \pm 0,81$ \\
\hline
\end{tabular}




\subsection{Bunches fruit characterization}

The overall average production during two cycles of underground system differed significantly from the drip irrigation $(5654.45 \mathrm{~kg} / \mathrm{year}, 4739.4 \mathrm{~kg} /$ year $)$ respectively. The average bunch mass and bunch fruit number were higher with a underground irrigation system compared to drip irrigation $(8.65 \mathrm{~kg} /$ bunch fruit, $7.9 \mathrm{~kg} / \mathrm{bunch}$ fruit, and, 652.5 bunch fruit, 595 bunch fruit )respectively (Table3). This indicates that the variability of these characters is not only genetic, but can be impacted by environmental parameters and management. The enhancement in both parameters was most likely due to the efficient use of water by the root system since it was straight provided to the absorbing functional zone. The yield parameter of date palm fruit of cv. 'Medjool' are improved with high reduction in irrigation water.

Table 3. Effect of irrigation systems on bunches fruit characteristics of 'Medjool' dates

\begin{tabular}{|c|c|c|c|}
\hline $\begin{array}{c}\text { Irrigation } \\
\text { system }\end{array}$ & $\begin{array}{c}\text { Bunch fruit number/ } \\
\text { tree }\end{array}$ & $\begin{array}{c}\text { Mean Production } \\
\text { (kg/tree) }\end{array}$ & $\begin{array}{c}\text { Mean overall } \\
\text { production (kg) }\end{array}$ \\
\hline Underground irrigation & $5,68 \pm 1,13$ & $49,22 \pm 10,09$ & $4739,40 \pm 132,60$ \\
\hline Drip irrigation & $5,03 \pm 1,87$ & $40,28 \pm 15,56$ & $5654,45 \pm 181,85$ \\
\hline
\end{tabular}

\section{Conclusion}

Finding ways to increase date palm production through irrigation systems is of great importance. This study presents the effect of irrigation systems on yield and physical quality of 'Medjool' dates of Figuig oasis, Morocco. The information is most important in deciding the suitability of different irrigation systems for date palm especially in regions limited in water resources. The results showed that irrigation systems significantly affected only mean overall production of date and seed weight, whilst fruit weight ,breadth and length, pulp thickness, stone width and stone length, were not significantly affected by irrigation. However, there were great savings of irrigation water using underground irrigation systems compared to drip irrigation system. In conclusion, the underground irrigation system improved physical characteristics of 'Medjool' date, but the differences were not significant.

\section{References}

1. P. Munier. Le Palmier dattier. Techniques agricoles et productions tropicales, Paris, 221(1973)

2. B. Agoudjil, A. Benchabane, A. Boudenne, L. Ibos, M. Fois, ISO4 43, 491-497 (2011)

3. A.H. El-Far, H.M. Shaheen, M.M. Abdel-Daim, S.K. Al Jaouni, S.A. Mousa, Curr. Drug Discov. Technol 16, 2-10 (2018) 
4. My.H. Sedra. Le palmier dattier base de la mise en valeur des oasis du Maroc, techniques phoenicicoles et création d'oasis INRA, Editions 266 (2003)

5. FAO. The future of food and agriculture - Trends and challenges, Rome (2017)

6. My.H. Sedra. Date Palm Status and Perspective in Morocco, Date Palm Genetic Resources and Utilization, 257-323 (2015)

7. A. Hasnaoui, M.A. Elhoumaizi, M. Sindic, J. Sci. Res 3, 139-149 (2010)

8. B. Ismail, I. Haffar, R. Baalbaki, Y. Mechref, J. Henry, Int. J. Food Sci 41, 919-926 (2006)

9. A.D. Al-Qurashi, J. Food. Agric. Environ 8, 404-408 (2010)

10. A. Aridah. Effect of Type of Irrigation System on Productivity and Income of Date Palm Growers in Sebha, Libya, thesis for the Degree of Doctor of Philosophy (2016)

11. I.A.R. Akasha. Study of quality attributes of some libyan dates. (Master thesis). Sebha University, Sebha, Libya (2005)

12. A. Al-Rawi, A.F. Al-Mohemdy. Effect of water quality on the growth and yield of date palm, in Proceedings of the Second International Conference on Date Palms, ICDP, 25-27 March 2001, Al-Ain, United Arab Emirates (2001)

13. F. Hussein, M.A. Hussein. Effect of irrigation on growth, yield and quality of dry date palm fruits grown in Aswan area, in Proceedings of the Second Symposium on Date Palm Trees, 27-30 May 2007, Alahsa, Saudi Arabia (1982)

14. A. Said, D. Kaoutrher, B. Ahmed, T. Mohammed, T. Brahim, Annu. Res. Rev. Biol 4, 487-499 (2014)

15. M. Shaheen, Met., Env. \& Arid Land Agric. Sci 18, 23-39 (2007)

16. A.G. Tafti, M. Fooladi, Res. J. Biol. Sci 5, 319-322 (2005)

17. I. Ullah, Physical characteristics of fruit of different date palm cultivars during various maturity stages, in Proceedings of the First International Scientific Conference for the Development of Date Palm and Dates Sector in the Arab World, Riyadh, Saudi Arabia (2011)

18. J.M. Basahi, Met., Env. \& Arid Land Agric. Sci 17, 26-42 (2006)

19. L. El-Juhany, Aust. J. Basic \& Appl. Sci 4, 3998-4010 (2010)

20. M. Shamsi, S. Mazloumzadeh, Agric. Sci. Technol 5, 17-31 (2009) 